\title{
EXILIO VITAL Y DRAMA DE ESPAÑA. EL SUSTRATO RELIGIOSO EN LA POESÍA DE LEÓN FELIPE
}

\author{
Juan Manuel Medrano \\ Universidad de La Rioja
}

En recuerdo de Ignacio Ellacuría y de sus compañeros mártires de la UCA

RESUMEN: El artículo pretende un acercamiento a la figura del poeta español Felipe Camino Galicia, León Felipe (1884-1968), a través de una interpretación de su obra, en la que el autor advierte la profunda influencia que el cristianismo -y también el Antiguo Testamento- tienen en su visión antropológica, en la construcción de sus imágenes poéticas y en el nervio ético-profético que recorre toda su obra. Para resaltar la dimensión de esta influencia, el autor recurre a la visión y postura que el poeta tiene del conflicto civil español de 1936-1939; además, confronta las imágenes y metáforas de León Felipe con la producción poética, también cargada de significaciones religiosas, que se está realizando en el bando franquista, tanto en las interpretaciones clericales de la contienda, como entre los poetas falangistas de aquel momento.

Palabras clave: Cristianismo, guerra civil española, exilio, Don Quijote, Carta Colectiva del episcopado español, poetas falangistas.

\section{VITAL EXILE AND SPANISH TRAGEDY IN THE POETRY OF LEÓN FELIPE}

ABSTRACT: The article aims for an approach to the figure of the Spanish poet Felipe Camino Galicia, León Felipe (1884-1968) through an interpretation of his work, in which the author notices the deep influence that Christianity -and, also, the Old Testament- have in his anthropological vision, in the construction of his poetic images and the ethical-prophetic nerve that runs throughout his work. To 
highlight the extent of this influence, the author uses the vision and stance that the poet has about the Spanish civil conflict of 1936 and 1939; in addition, he compares the images and metaphors of León Felipe to the poetic production, also full of religious meanings, which is being made in the pro-Franco side, both in the clerical interpretations of the war, and among the falangist poets of that time.

Keywords: Christianity, Spanish civil war, exile, Don Quixote, Collective Letter from the Spanish episcopate, falangist poets.

La vieja herencia de los verdaderos santos de todas las épocas y de todos los tiempos; la herencia de los poetas prometeicos inmortales es vuestra. Lo demás del mundo de hoy es sólo catolicismo sin motor, orden sin justicia y beatería patológica. Y cuando alguien os diga que vosotros sois los sin-Dios, responded: pero si nosotros somos Dios mismo; la justicia viva; los defensores de la justicia

"El payaso de las bofetadas y el pescador de caña" (1938)

\section{La singularidad poética de León Felipe}

León Felipe (Tabara, Zamora, 1894, Méjico, 1968) constituye un caso singular dentro del grupo de poetas que se compromete en alma y vida con la causa del bando republicano; singular -aunque no único- escritor cuyo aliento poético y actitud vital y moral es de raíz esencialmente religiosa. Un creador que toma buena parte de su fuerza ideológica y contenido metafórico y simbólico de la tradición religiosa, tanto del Antiguo como del Nuevo Testamento. Y no siendo el único, como decíamos, sí es con seguridad el poeta español de aquella generación que más profundamente ha concebido sus temas y la propia experiencia personal plasmada en su obra en términos cuasi proféticos.

No es nuestra pretensión con este artículo indagar acerca de las cualidades poéticas de León Felipe. Pretendemos centrar nuestra atención especialmente en el universo poético que crea en los años mismos de la guerra civil, recurriendo también a una parte de su producción en el exilio de Méjico. Nuestra intención es confrontar las imágenes y elementos poéticos de naturaleza religiosa de la poesía de León Felipe en relación con el tema vertebral de su pensamiento, que no es 
otro -a nuestro juicio- que la condición vital del hombre como "exiliado" en la existencia. A la vez, será interesante contraponer estos elementos -que tienen una profunda raíz religiosa- para confrontarlos polémicamente con el trasfondo que idénticas imágenes y motivos religiosos tienen en el bando franquista, singularmente en algunos poetas falangistas. Para ello, nos será necesario recorrer una parte esencial del imaginario poético y vital de León Felipe, que nos es otro que el "drama" de España, la tragedia de su enfrentamiento civil; tragedia concebida simbólica y alegóricamente como un "sacrificio" estructuralmente similar al sufrido por el "inocente" Cristo. Ello al mismo tiempo que -como sabemos- en el otro bando los escritores enemigos de la República utilizan la misma figura clave como arsenal simbólico y poético con una intención diametralmente opuesta.

No insistiremos más de lo necesario en recordar los hechos biográficos esenciales del poeta con intención de ayudar a situarlo. León Felipe es un ejemplo máximo donde "biografía" personal, historia colectiva y obra poética se funden en una sola realidad'.

Poeta tardío y de difícil encaje generacional, publica su primer libro, Versos y oraciones de caminante, en 1920, al que seguirá un segundo con el mismo título en 1930. En su madurez poética de los años treinta destaca Drop a Star (1933) y sus obras en pleno conflicto civil, La Insignia (1937), El poeta de las bofetadas y el pescador de caña (1938), que serán especialmente citados en este trabajo. Tras la derrota republicana, y ya en México, publicará toda su obra del exilio, desde El Hacha y Español del éxodo y del llanto, ambas de 1939, pasando por la fundamental Ganarás la luz de 1943, hasta sus últimas y tardías obras, entre las que destacamos ;Oh, este viejo y roto violín! (1965) y la póstuma Rocinante (1969).

Respecto a sus influencias y temas dominantes, recordemos que se ha hablado a menudo de la "singularidad" de León Felipe como poeta; de la difícil clasificación de su poesía y de su no adscripción a ninguna de las "generaciones" del siglo XX. Max Aub decía que constituía -él solo- una generación, aunque se han hecho esfuerzos académicos notables para incorporarlo a sus coetáneos ${ }^{2}$. En cualquier caso, es una cuestión siempre abierta que se aparta del propósito de este artículo. Más interesante para nosotros es rastrear el eco de las influencias que más claramente se manifiestan en su obra poética. Se citan como evidentes las de Shakespeare, Whitman, Nietzsche, la tragedia clásica y sus mitos (Prometeo) y la bíblica. Naturalmente, hay que añadir la enorme influencia que la tradición literaria española ejerce sobre él: singularmente la Mística y la de Cervantes, dado que Don Quijote, Sancho -y Rocinante- aparecen constantemente en sus versos y en sus títulos. A nuestro propósito escapa profundizar en este cúmulo

1. Así lo manifiestan todos los estudios sobre su obra, recogiendo sus propios versos. Para esta breve referencia biográfica seguiremos la introducción de José Paulino a las Poesías Completas de Léon Felipe, Madrid, Visor, 2004.

2. Recomendamos la abundante bibliografía reseñada por José Paulino en la edición de las Poesías Completas de León Felipe, Madrid, Visor, 2004. 
de influencias, puesto que hemos de centrarnos en una de las más poderosas y constantes, la bíblica, precisamente para verla confrontar simbólicamente con la temática "religiosa" que se despliega en el bando franquista. No obstante, en la medida en que, al igual que Unamuno, León Felipe vive la experiencia quijotesca como una suerte de religión, también habremos de apuntar a esta emblemática figura en más de una ocasión. Convendría, no obstante, formular lo coherente de establecer vínculos entre la poesía de León Felipe y el pensamiento nietzscheano, especialmente el que encarna en la figura del persa Zaratustra.

\section{La especial situación del poeta en el bando republicano}

León Felipe escribe y combate con absoluta convicción y entrega a favor del bando republicano. Es más, pretenderá apurar hasta sus últimas consecuencias tal causa, que él identifica inequívocamente con la causa de la "Justicia". Consciente de una derrota prácticamente segura en su obra de 1937, abomina no obstante de cualquier componenda o huida de la responsabilidad "heroica" que toca a los hombres y mujeres de la República:

Hay dos vientos hoy que sacuden furiosos a los hombres de España, dos ráfagas que empujan a los hombres de Valencia.

El viento dramático de los grandes destinos, que arrastra a los héroes a la victoria o a la muerte,

y la ráfaga de pánicos incontrolables que se lleva la carne muerta y podrida de los naufragios a las playas de la cobardía y el silencio ${ }^{3}$

Quien no cumpla con su deber hasta el final recibirá un castigo eterno:

Una vez más veré el rebaño de los cobardes huir hacia el ludibrio.

Una vez más veré en piara la cobardía.

Os veré otra vez,

asaltando, con los ojos desorbitados, los autobuses de la evacuación.

Os veré otra vez

robándole el asiento

a los niños y a las madres

$[\ldots]$

...Y allá, al otro lado, cuando ya no seáis más que una conciencia suelta, en el tiempo y en el espacio, y caigáis precipitados al fin en los tormentos dantescos - porque yo creo en el infierno también- no os veréis más que así,

siempre, siempre, siempre,

robándole el asiento a un niño en un autobús de evacuación.

3. La insignia, 1937. 
El castigo del cobarde ya sin paz y sin salvación por toda la eternidad. ${ }^{4}$

A la vez, la posición de León Felipe es profundamente crítica con la división e intereses partidistas de aquellos que defienden la legalidad republicana. Tal y como él concibe la contienda, como la situación histórica más importante vivida por España, como un enfrentamiento en términos casi apocalípticos, las facciones, los colores, y los motivos particulares de cada "ideología" concreta dentro del bando republicano, le parecen de una veleidad intolerable. Una "avaricia", dice en La Insignia, peor que la de los "burgueses":

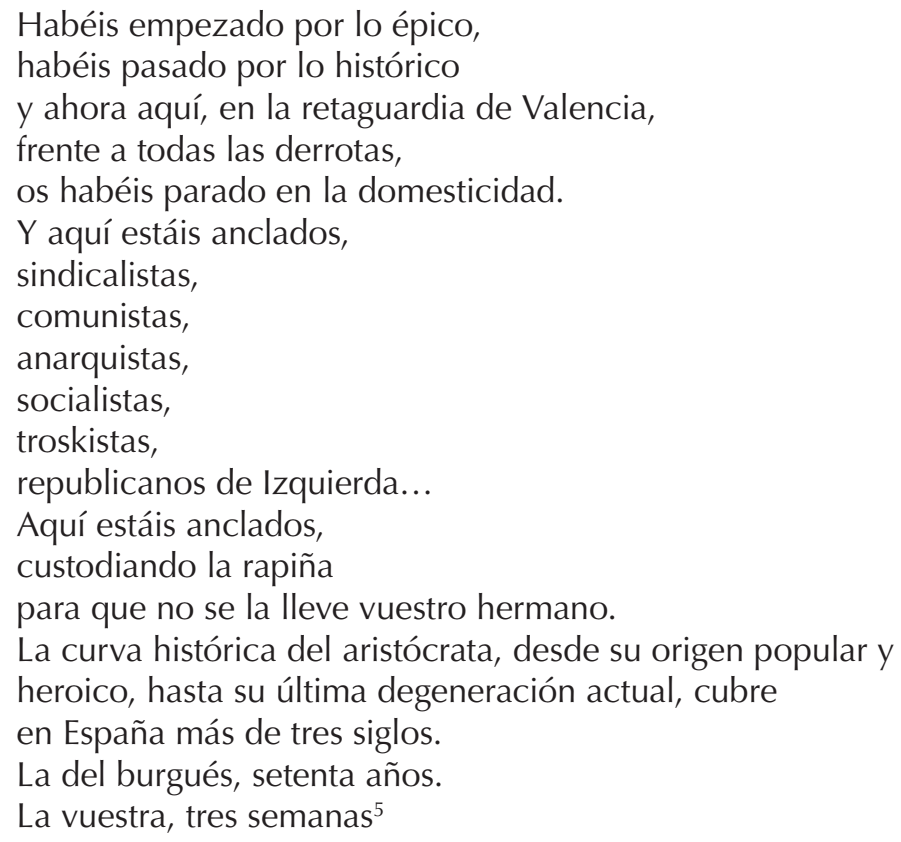

La razón principal -entendemos- de esta radical singularidad del poeta respecto a tantos intelectuales del bando republicano estriba en esa concepción de la justicia que es inmediatamente identificada con el "amor" ("Por amor se hacen las revoluciones y se establece la política. Lo llamamos justicia, pero no es más que amor"6); una concepción de la justicia-amor que, creemos, no tiene una dimensión tanto ideológico-racional como verdaderamente emotivo-profética; concepción procedente de un arraigo profundo del cristianismo en la mentalidad de León Felipe; un cristianismo de raíz dualista griega ("Y están también los terremotos que rompen la tierra, / desgarran la carne, / desbordan los ríos / y las arterias de nuestra anatomía/ para dar salida al
4. Ibídem.
5. Ibídem, p. 196.
6. El payaso de las bofetadas, "Que la justicia existe". 
espíritu encadenado/ y mostrarle su camino hacia la renovación y hacia la luz" ${ }^{7}$ ). Tal concepción encuentra en la división de España en dos bandos en guerra una ocasión real y poética a la vez de manifestarse con toda su fuerza. A pesar de todo, como sabemos, el compromiso de León Felipe con el bando republicano es absoluto, pese a ser consciente de paradojas tan graves como ésta:

Con la justicia no se puede jugar, y con un arzobispo criminal no se puede pactar. Un español no puede pactar con él aunque sea comunista, pero al comunismo ruso de hoy, al revés que a la España legítima, le interesa más ser católico que ser cristiano, le interesa más el orden que la justicia. Le interesa más la forma que la esencia ${ }^{8}$

Porque, en realidad, la guerra civil no es un enfrentamiento de ideologías o concepciones de la sociedad, sino algo más esencial:

Y que no pregunte ya más ese espectador de ring con alma de bodeguero: ¿Cree usted que el queso se lo comerán las ratas blancas o las ratas rojas? Porque no se trata de que triunfe este o aquel español, sino de salvar al hombre ${ }^{9}$

Y es que a España, a la España republicana, le ha tocado defender la bandera antigua y eterna de la justicia, sin la cual, aunque haya orden, no se puede organizar el mundo de ninguna manera:

Si esta ley [la de la justicia] se rompe, se descompone o se debilita, no puede haber orden entre los hombres, aunque se llenen las audiencias de magistrados y las calles de policías [...] El orden no es más que una consecuencia de la justicia ${ }^{10}$

Y esta eterna-justicia amor es la parábola evangélica que viene "cruzando los cielos desde hace veinte siglos".

\section{Las raíces religiosas de su poesía}

Hablamos de la profunda emoción religiosa que recorre la obra y la personalidad de León Felipe. Es un hecho patente que no ha escapado a ningún trabajo crítico sobre su obra, aunque quizás no se le haya dado el relieve que merece a la hora de singularizar el nervio moral que recorre su poesía. Es difícil no reconocer en la imagen física de León Felipe algo de "profeta", de la actitud severa y ascética, que recuerda a los antiguos profetas de Israel. Y ocurre

7. Ibídem.

8. Ibídem.

9. Ibídem.

10. Ibídem. 
lo mismo con su lenguaje, que no solo toma del salmo bíblico su ritmo, sino también su intención. ${ }^{11}$ Es su aspecto, su misión poética llena de advertencias, imprecaciones, juramentos y condenaciones eternas que alcanza su paroxismo en las obras de la guerra civil y del primer exilio; denuestos cuyo clímax acontece precisamente cuando se dirigen contra los representantes eclesiásticos que bendicen la causa franquista, como veremos.

Religiosa es en León Felipe una vocación y una realidad vital de pobreza, una concepción de la miseria humana y de la realidad injusta e insuficiente del mundo; religiosa es su cosmovisión dualista, que se mueve desde el plano de la realidad: el "Ilanto", hasta la búsqueda de una salvación (colectiva): la "luz"; religiosa es una concepción de la vida como peregrinaje, una continua apelación a Dios y a su obra y una inextirpable sed de revolución escatológica que se articula como "Justicia". Veamos en detalle algunos de estos temas.

\section{El hombre como tierra de "exilio"}

Si tuviéramos que resumir o esenciar los temas dominantes de la poesía de León Felipe deberíamos reducirlos a dos, que constituyen en realidad un único tema: la debilidad intrínseca del ser humano, fruto de su personal situación de exiliado en la existencia.

Efectivamente, todo, y desde el principio, en la poesía de León Felipe apunta a una condición de "provisionalidad" en la existencia humana, como si el ser hubiera sido arrojado (a la manera heideggeriana), definitivamente solitario, a una existencia que es -conforme a la visión cristiano-paulina- un exilio temporal tensionado hacia una "luz" o redención final ${ }^{12}$. Tal exilio humano es fundamentalmente "interior", pero los acontecimientos históricos en que se ve envuelta la existencia personal pueden acabar funcionando como una metáfora que transmute una realidad estructural de cada ser humano en un acontecimiento colectivo e histórico. Y el acontecimiento que opera esta realidad en toda su crudeza poética y vital va a ser -en la biografía de nuestro poeta- el drama de la España republicana.

Desde sus primeras obras, esa sensación humana de desorientación vital, de hallarse en un mundo que no encaja, en una especie de destierro para el alma, se manifiesta poéticamente bajo la forma de una existencia como peregrinaje solitario e intensamente personal. Ello es claro desde su obra inicial, Versos y Oraciones de Caminante (1920):

¡Qué solo estoy Señor, qué solo y qué rendido

11. Así lo reconoce José Paulino en la citada introducción a la obra poética de León Felipe, pág. 14.

12. Numerosos textos de Pablo recogen esta tensión entre un "ahora" profundamente imperfecto y un "entonces" futuro de plenitud. Por ejemplo 1 Cor 13: 12. 


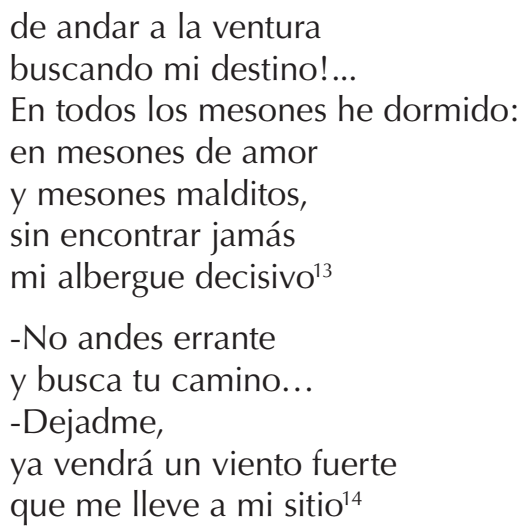

La situación solitaria y confundida del hombre -de tradición claramente bíblica- no desaparecerá jamás ni en el joven ni en el anciano León Felipe. Todo mostrará en su obra una insatisfacción vital y un oscuro conocimiento de que el reposo y la verdad que busca el ser no se encuentran en las cosas, ni en el mundo real al que se accede por los sentidos; y no, desde luego, en la condición humana. Hay en ese mundo poético una difusa angustia, un anhelo indefinible de algo a lo que el poeta llamará "Dios", "Viento" o "Luz". Pareciera que León Felipe hiciera buenas las palabras de Zaratustra, que predicaba la realidad del hombre como tránsito a una forma superior de humanidad:

El hombre es una cuerda tendida entre el animal y el superhombre -una cuerda sobre un abismo

\section{[...]}

La grandeza del hombre está en ser un puente y no una meta: lo que en el hombre se puede amar es que es un tránsito y un ocaso ${ }^{15}$

Esa condición peregrina, aislada, del ser humano León Felipe, que no se identifica con patricios ni plebeyos, tomará un giro decisivo cuando el drama de la II República y de la guerra civil haga al poeta sentirse solidario con una causa -que a pesar de las miserias ideológicas que la estrangulan- es la causa de la verdadera justicia, otra vez interpretada en términos religiosos, puesto que -como veremos- la España-mártir es también el Cristo crucificado y abandonado.

13. Versos y Oraciones de caminante (VOC), poema XVI.

14. Ibídem, poema XXVI. Como es conocido la voz "viento" significa en hebreo igualmente "aliento", "soplo del espíritu divino".

15. F. Nietzsche, Así habló Zaratustra, Prólogo, IV. A propósito de Nietzsche, se podría aplicar a nuestro poeta castellano la misma interpretación que el teólogo Bernhard Welte aplicaba al filósofo alemán, esto es, "haber descubierto la tendencia que vive en la raíz de la humanidad a su salvación suprema" (B. Welte, El ateísmo de Nietzsche y el cristianismo, Madrid, Taurus, 1961, p. 64). 
Terminado el conflicto, la realidad del exilio -por decirlo de alguna manera"socializa" el exilio interior del poeta en el destino común de la España republicana. A partir de ahora, de una manera más aguda que nunca, esa condición exílica del hombre León Felipe y de su pueblo, toma forma literaria en las figuras más notables de la "Hispanidad": Don Quijote, Sancho, Rocinante.

Y es que-como decíamos- la condición exiliada de la existencia no es sino el reverso de la intrínseca debilidad constitutiva del hombre.

\section{El hombre como "debilidad" redimible}

El hombre mismo -para nuestro poeta- está recorrido por un doble aspecto: una especie de debilidad intrínseca, estructural (una de las metáforas y símbolos más recurrentes es el de "barro"), una insuficiencia vital como individuo -a menudo categorizada como "pecado" - y una posibilidad siempre absoluta de redención o de gracia:

La manzana roja que me dieron a comer ayer tenía un gusano:

La manzana blanca que se comieron mis padres tenía dos gusanos;

y la manzana verde que se comió la pareja original, ya en la puerta falsa del Paraíso, tenía ya tantos gusanos

que todos pudimos heredar nuestra parte.

La redención definitiva del hombre no hay que buscarla en el pasado, pertenece -escatológicamente- al futuro, como dice el verso que sigue a los anteriores:

Si hay una manzana sin gusanos en el mundo no está detrás de mí mismo sino delante ${ }^{16}$

Profundizando más en esta concepción del hombre como debilidad o "enfermedad", dice León Felipe:

Yo no soy nada,

un hombre con un grito de estopa en la garganta

y una gota de asfalto en la retina ${ }^{17} .$.

Existen dos realidades humanas, que León Felipe adjetiva a veces como la "historia" con minúsculas ("-la otra, la Historia doméstica, / la Historia nacional, / no es más que un registro de mentiras / y un índice de crímenes y vanidades"18) y la "Historia" con mayúsculas. La constitución habitual del hombre, por sus pecados, por su codicia y por su vulgaridad, además de por el capricho de los dioses ("estrellas

16. Ganarás la luz (GL), "Las tres manzanas podridas", edición de José Paulino, p. 224.

17. GL, "Tal vez me llamé Jonás".

18. El payaso de las bofetadas y el pescador de caña (PB), "El payaso tiene la palabra"). 
dictadoras nos gobiernan") es no haber salido del "barro" primigenio de la creación, realizar una sociedad sórdida donde falta el elemento esencial, la Justicia. A la vez, el hombre es capaz, a través del poeta "prometeico" (y de todas sus encarnaciones: Edipo, Don Quijote, Fausto, Zaratustra) ${ }^{19}$, de poner el mundo patas arriba y tratar de realizar la gran revolución, metafórica y real ("¿Qué es una revolución más que una metáfora social?"20), que es la realización de la Justicia en el mundo, algo que -recuerda constantemente el poeta- sólo se puede hacer con el precio de mucha sangre ("Los dioses lo tienen todo, hasta el silencio. Con su sangre el hombre puede negociar con los hados, derribar las sombras, desbaratar el signo de las estrellas y producir la gran metáfora sideral"21). El hombre que mejor y antes se ha dado cuenta de cuál es la verdadera misión en el mundo es, por capricho de Dios, el español:

España, la verdadera España, la España de las esencias, está de vuelta de todas esas aventuras de ambiciones imperiales que ahora mueven a los pueblos totalitarios. Los problemas de esos pueblos son epidemias infantiles que España venció hace ya tiempo a costa de mucha sangre y de muchos errores. El problema eterno de España, el de ayer y el de hoy y el que no ha resuelto todavía, no es el problema del imperio, sino el problema del hombre [...] Es un pueblo [España] que tiene como ningún europeo la capacidad prometeica de transbordo, la gracia poética de anteponer lo esencial y eterno del hombre a lo contingente y episódico de la vida: a su hacienda, a su casa, a su familia, a su ciudad, a su patria ${ }^{22}$

\section{Una dualidad de mundos}

En la misma línea en la que existen dos "historias", la vulgar y la prometeica que busca la Justicia, enraizando con una tradición profundamente cristiana y paulina, se da una duplicación de lo real en dos planos, en dos mundos, el mundo de las "apariencias" engañosas y el mundo de las "esencias" (lo que, en la lógica de la Guerra Civil es reducido a dos bandos en liza ${ }^{23}$ ):

Hay dos mundos: el de las formas y el de las esencias

[...]

En el mundo de las formas desgastadas

están los símbolos obliterados,

los ritos sin sentido,

19. Ibídem, "Don Quijote no es una entelequia".

20. Ibídem, "El poeta prometeico".

21. Ibídem.

22. Ibídem, "El hombre es lo que importa".

23. "En España ya no hay más que dos posiciones fijas e inconmovibles. /Para hoy y para mañana./ La de los que alzan la mano para decir cínicamente: Yo soy un bastardo español,/ y la de los que la cierran con ira para pedir justicia bajo los cielos implacables" (La Insignia.) 
los uniformes inflados, las medallas sin leyenda, los hombres huecos, los cuerpos de serrín, el ritmo doméstico y sonámbulo, la exégesis farisaica, el verso vano, y la oración muerta que van contando las avellanas horadadas de los rosarios.

Dios, la fuerza original y creadora, se ha ido de este mundo y todo se ha quedado sin substancia ${ }^{24}$

La vida como peregrinaje hacia la "luz"

La existencia del hombre es un continuo caminar o peregrinar hasta saber cómo se llama:

Mi yo está formado de un barro antiguo, de un pulso urgente y de un resplandor lejano.

Detrás de mí hay unas huellas sucias; delante, el guiño de un relámpago en la sombra y dentro de mi corazón, un deseo rabioso de saber cómo me llamo ${ }^{25}$

Desde su primer libro la vida es entendida en sentido cristiano como tránsito hacia una realidad transfigurada. Desde el primer poema, Dios es el gran interlocutor del poeta:

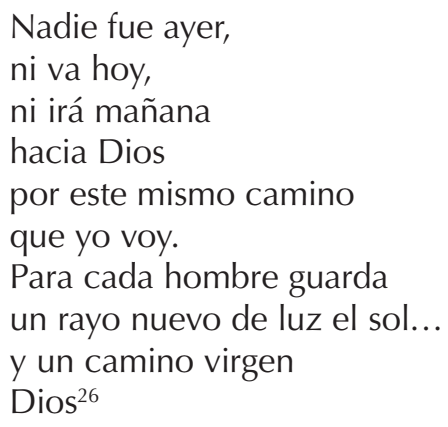

La existencia humana está llena de dolor, dolor que procede de una incomprensión del ser mismo, que debe caminar toda la vida para encontrar su verdadero nombre; y el dolor de un mundo injusto, mal hecho, que debe ser trans-

24. GL, Libro III: Prometeo, "Los dos mundos".

25. Ibídem, Libro Primero, \#2 "Quisiera decir cómo me llamo".

26. Versos y Oraciones de Caminante, I. 
figurado (a la manera en que lo intenta Don Quijote) en un mundo que sea digno hogar del hombre, un mundo de "Justicia". Aunque la guerra civil lleve al paroxismo esa concepción desgraciada de la existencia histórica del hombre, León Felipe arrastraba antes y llevará más allá del exilio esta concepción antropológica. La metáfora para expresar este indefinible dolor -que no puede ser de mayor tradición cristiana- es "Ilanto". Y la purificación del hombre y del mundo toma forma en otra metáfora cristiana por excelencia: "luz". Y ese es el recorrido, el proceso, que tiene que atravesar todo hombre:

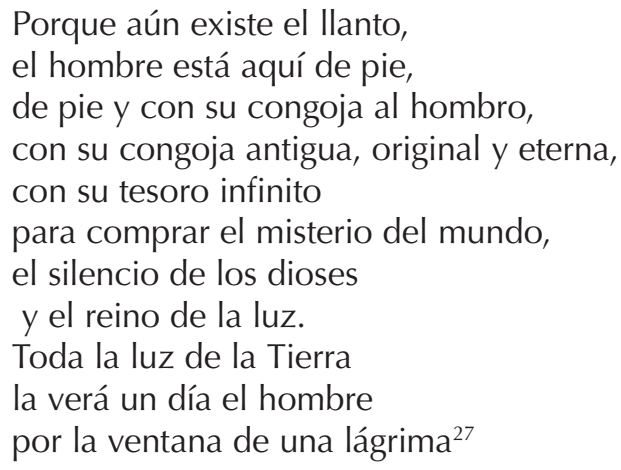

Don Quijote como religión española

Don Quijote es el "héroe" por excelencia del poeta. Trasunto de Cristo, de Prometeo, es un poeta "activo y del trasbordo" que tiene una misión que cumplir cuando:

El hombre doméstico, egoísta y tramposo, degrada el mundo y todo lo rebaja [...] La primera aventura [de Don Quijote] surge cuando el poeta se encuentra con la realidad sórdida del mundo, después de salir de su casa, llevando en la mano la Justicia [...] Porque no hay más que una hazaña en toda la crónica: el trastrueque, el trasbordo de un mundo a otro mundo; de un mundo ruin a un mundo noble. Aparentemente no es más que una hazaña poética, una metáfora. Pero es una hazaña revolucionaria también, porque ¿qué es una revolución más que una metáfora social? ${ }^{28}$

Don Quijote es el símbolo más reiterado en la poesía de León Felipe, símbolo aparentemente múltiple y en el fondo único: él es el poeta prometeico que representa la esencia eterna del hombre que se rebela contra un mundo injusto y mal

27. Español del Éxodo y del llanto; citado en José Paulino, introducción a GL, pp. 39-40.

28. GL, Libro III, "El poeta prometeico". 
construido. No es posible que el mundo sea aquello con lo que Alonso Quijano se encuentra en la venta:

Con un albergue sucio e incómodo, con un hombre grosero y ladrón, con unas prostitutas descaradas, con una comida escasa y rancia, y con el pito estridente de un castrador de puercos ${ }^{29}$

Pero, de una manera más inmediata, Don Quijote es ahora -en el año 1938parte de la España legítima, de la España republicana:

España es el sueño de Don Quijote. Y Don Quijote no es más que la España legítima, viva y actual ${ }^{30}$

Don Quijote es el gobierno español que suplica por que se cumpla la "legalidad" internacional ("¿Quién no le ha oído gritar pidiendo justicia en los tribunales de Ginebra?" [sede de la Sociedad de Naciones]). Don Quijote es en 1938 el "Payaso de las bofetadas" que da título a su libro de ese año, pero que incluso, en pleno fragor del combate contra el otro bando, el bando del "bachiller traidor y bastardo", incluso ante la terrible realidad ("...hace tres semanas cuando en Barcelona las toneladas de trilita cayeron sobre los nietos indefensos de este pobre payaso" $)^{31}$, Don Quijote no deja de ser un símbolo universal que trasciende la tragedia de España:

No está loco. Está en un grado de humanidad al que no ha llegado casi ningún hombre todavía [...] Don Quijote sale a poner en práctica su evangelio español, el evangelio de la justicia, que ahora conviene recordar para que sepamos todos quién es su legítimo heredero y por dónde se ha de trazar la línea divisoria que parta España. Porque la línea no se ha trazado bien. Por lo menos no se ha trazado con medidas españolas. Que no se trata de comunismo ni de fascismo. La cuestión es más vieja y viene de más alto ${ }^{32}$

\section{España $=$ Cristo}

La imagen más potente sin duda de toda la poesía profética de León Felipe, la más escandalosamente intolerable para los católicos del bando franquista es la identificación sin ambages del destino de España con el de Cristo. Cristo y España, interpretados como símbolos inocentes traicionados por el mal, son motivos recurrentes en toda la obra del poeta escrita en tiempo de guerra y en el primer

29. $P B$, "El poeta prometeico".

30. Ibídem., "Don Quijote no es una entelequia".

31. Ibídem, "El payaso de las bofetadas".

32. Ibídem, "Don Quijote no es una entelequia". 
exilio mejicano. Son tantos los versos que sirven a este propósito que nos limitaremos a apuntar algunos. Así, en El payaso de las bofetadas, hay una referencia a Cristo, enmarcada en una evidente paráfrasis de la famosa referencia de Pablo a la caridad (1 Cor, 12):

Y Cristo... no es más que caridad. ¡Caridad! ¡Caridad! Si yo no tengo caridad, habrá muchos hombres que no tengan nunca nada, y mis riquezas inagotables no podré repartirlas jamás entre los humildes. Porque si yo no las reparto, ¿quién las va a repartir? ¿Qué ley, qué poder, qué autoridad en el mundo me va a arrancar a mí del pecho, si yo no quiero, ese diamante que me sobra? ${ }^{33}$

Y en Ganarás la Luz:

El verbo lírico de Cristo y de todos los poetas del mundo es retórica es un índice luminoso que nos invita a la acción y al heroísmo. Y esta metáfora del camello y de la aguja, del pobre y del rico tiene un sentido que desentrañado y realizado, puede llenar, si no de alegría, de dignidad la vida del hombre ${ }^{34}$

Y también:

Sola y en cruz... España-Cristo, con la lanza cainita clavada en el costado, sola y desnuda, jugándose mi túnica dos soldados extraños y vesánicos; sola y desamparada.

Mirad cómo se lava las manos el pretor

La antítesis de Cristo-España toma los rostros del obispo que bendice los cañones de Franco, el Gran Conserje Pedro (imagen anticrística por excelencia) ${ }^{35}$, el papa, etc.

España-Cristo es acompañada por otra serie de metáforas de identificación que surgen a menudo, como Don Quijote, Prometeo, Jonás, etc.; pero hemos

33. Ibídem, "Que la justicia existe".

34. GL, Libro III, Prometeo, "Los dos mundos". Parece difícil no interpretar la expresión "desentrañado y realizado" como la obra de justicia social que se propuso la II República. Por otra parte, tal vez estemos también en alguno de los momentos donde Nietzsche planea sobre la escritura de León Felipe: "Hay que salvar al rico y al pobre/ Hay que matar al rico y al pobre para que nazca el hombre. / El hombre, el hombre heroico es lo que importa" (El payaso de las bofetadas, "Que la Justicia existe").

35. "Pedro, Pedro.../ el Gran Conserje Pedro/ que ha vendido las llaves del templo / Pedro.../ Te dijo el Señor en los Olivos / cuando heriste con tu espada al siervo: / Mete esa espada en la vaina, / que yo sé a lo que vengo. / Y la metiste...con la caja de caudales en el templo". (Libro VIII, Hacia el infierno, "Yo soy el gran blasfemo"). 
querido resaltar la imagen de Cristo-España para oponerla a la retórica que se produce en el otro bando, como veremos.

\section{Una salida escatológica: Viento, Luz, Hispanidad}

La estructura cristiano-paulina de León Felipe dibuja naturalmente una salida escatológica, una forma de redención final. De la misma manera que Cristo atraviesa la muerte para "resucitar" y vencerla (Hechos, 13: 26-33), el individuo, por un lado, y España, por otro, gozarán algún día de una forma de plenitud. A través de las metáforas del "viento" o de la "luz", al hombre le está reservada la "salvación"36 tras un itinerario vital de dolor y sufrimiento. La resurrección de España tomará en el poeta la forma de "Hispanidad", una nueva "tierra prometida" para el sufriente pueblo español:

Para crear la hispanidad hay que morir porque sobra el cuerpo.

Murió el héroe y morirá su pueblo,

murió el Cristo y morirá la tribu toda: que el Cristo redentor será ahora un grupo entero

de hombres crucificados, que al tercer día han de resucitar de entre los muertos...

Hispanidad será este espíritu que saldrá de la sangre y de la tumba de España... para escribir un Evangelio nuevo. ${ }^{37}$

Ciertamente, el lenguaje poético de León Felipe se vuelve menos "feroz" conforme la tragedia española de 1936-1939 va quedando atrás. En el exilio mejicano los versos del poeta ya no expresan el fragor del combate, de los dos bandos en liza. La asunción de la derrota en el plano fáctico y real es absoluta, de manera que la poética de León Felipe se vuelve más nostálgica por la pérdida de la verdadera España y por la oportunidad perdida por la "Justicia". Esto parece claro en obras como Español del éxodo y del Ilanto, Llamadme Publicano o Ganarás la Luz. No obstante, todavía en esta última obra mencionada, de 1943, dedica León Felipe toda una parte del libro a la patria perdida, el Libro V, "Sobre mi patria y

36. "Cuando lleguemos a la Gran Puerta, sin documentos ya, y con todos los caminos arrollados bajo el brazo como planos inservibles, diremos todos la misma palabra: Hombre" (GL, Libro I, "Quisiera decir cómo me llamo". También: "Y allá, / más allá del mar... / al final de mis lágrimas/ está la isla que busca el navegante/". (Libro II, La esclava, "Navega"). Sobre la metáfora de la luz: "Para ganar esta luz vine y estoy aquí; por ganar esta luz me iré y volveré mil veces en el viento; por ganar esta luz entraré por la puerta norte y saldré por el postigo del infierno./ Por ganar esta luz se han vertido hasta hoy todas las lágrimas del mundo/ y por ganar esta luz tendrán que llorar todavía inmensamente los hombres./ (Libro VII, La Poesía, "Tal vez sea la luz").

37. GL, Libro V, Sobre mi patria y otras circunstancias, "Ahora definiré la Hispanidad". 
otras circunstancias". Su poesía ha perdido agresividad y se vuelve hacia España con la mirada típica de exiliado:

Mi patria está ahora donde se encuentre aquel pájaro luminoso que vivió hace tiempo en mi heredad ${ }^{38}$

La herida de la contienda, no obstante, sigue fresca. Y España, personificada en el siguiente poema habla de su propia muerte a manos de "mercaderes", de "vendedores de sombras". España es otra vez, aún, España-Cristo "con la lanza cainita clavada en el costado". Sin embargo, su poesía va dejando atrás la problemática concreta de la reciente guerra, haciéndose más "universal" temáticamente, recurriendo a los eternos temas de la justicia y la injusticia, el origen y destino del hombre, su redención (que ahora se llamará "Hispanidad", como decíamos). Conservará -eso sí- las figuras emblemáticas españolas, surgidas de la imaginación de Cervantes, hasta sus últimos poemas y libros. El consuelo de León Felipe será que la España republicana, en su exilio definitivo, se habrá llevado la "esencia" de la España verdadera, dejando en el costado de Europa una patria "huérfana", un yermo conquistado por los franquistas:

Soldado, tuya es la herencia,

la casa,

el caballo

y la pistola.

Mía es la voz antigua de la tierra.

Tú te quedas con todo y me dejas desnudo y errante por el mundo...

Mas yo te dejo mudo... ¡mudo!

y ¿cómo vas a recoger el trigo

y a alimentar el fuego

si yo me llevo la canción ${ }^{39}$

Sin embargo, vamos a verlo, también los hombres del otro bando tenían canciones.

\section{Nacionalcatolicismo frente a cristianismo profético}

Nadie desconoce que la retórica del bando contrario a León Felipe, al que por sintetizar Ilamaremos "franquista", está absolutamente llena desde el principio de referencias religiosas, y no solo por parte de la Iglesia católica, una mayoría de la cual se pone inmediatamente al servicio de la rebelión militar ${ }^{40}$. Como veremos, los

38. GL, 1 "Diré algo más de mi patria".

39. GL, Libro I, Algunas señas autobiográficas, "Hay dos Españas".

40. El propio Franco, antes incluso que los obispos españoles, utiliza elementos referenciales claramente religiosos desde sus primeras arengas en territorio africano, utilizando ya el término "cruzada", o hablando de "movimiento salvador y redentor" (en López Campillo y 
intelectuales católicos, falangistas o católico-falangistas a la vez, no dejan de invocar continuamente elementos religiosos en sus poemas y escritos. Mostraremos de forma sumaria el tono de las proclamas eclesiásticas y el que deriva de alguna obra especialmente significativa de los intelectuales rebeldes, como es el caso del joven José María Pemán. Nuestro propósito será mostrar cómo -pese a similares imágenes y referencias- el fondo ético-religioso de León Felipe es radicalmente distinto al que se utiliza en el bando franquista. Por sintetizar, diríamos que mientras el poeta del bando republicano se expresa desde un fondo insobornablemente ético-moral, próximo en la forma y el fondo a los profetas del Antiguo Testamento y a los Sinópticos, quienes hablan poética o doctrinalmente desde el bando franquista -obispos y escritores- lo hacen desde un fondo histórico-teológico, bajo el dictado de una catolicidad esencial de la nación española; bajo tonos a menudo profundamente apocalípticos (Pemán), en el sentido de incluir la contienda civil entre españoles dentro de un "ciclo" teológico de enfrentamiento entre el Bien y el Mal (la Bestia y el Ángel en la terminología pemaniana).

\section{La "resurrección de España" para Cristo}

"Resucitar España para Cristo"41: una expresión frecuente que resume -como un lema- la postura de la jerarquía y también de las fuerzas católicas, monárquicas, carlistas y falangistas, que combaten contra el bando republicano, el bando de León Felipe, la "anti-España".

En el bando franquista, en plena guerra civil, y en parte ante las noticias de la masacre de varios obispos y algunos miles de sacerdotes y seminaristas ${ }^{42}$, la rebelión militar toma tempranamente -como es sabido- la forma de "cruzada" religiosa. Dos documentos son esenciales en este proceso: la pastoral "Las dos ciudades", que publica Enrique Pla i Daniel en Salamanca el 30 de septiembre de 1936, y la famosa pastoral conjunta de los obispos, anhelada por Franco, básicamente obra de Isidro Gomá, que se publica el 1 de julio de 1937. De ellas nos interesará únicamente referir aquellas expresiones y temas que conecten, como contrapunto, con las imágenes bíblicas y neotestamentarias que surgen de la pluma de León Felipe.

Por otra parte, aunque no todos los poetas del bando franquista son falangistas, viejos o nuevos, ni todos son inequívocamente católicos, se producirá en esos años una poesía de fuertes connotaciones religiosas y escatológicas, que podremos comparar con el impulso poético -también religioso-escatológico- de León Felipe. Nos limitaremos a comentar algunos textos representativos, inci-

otros, “Una cruzada para una nueva Tierra Santa ¡Fraternidad, Libertad, Igualdad!”, Norba 14, Revista de Historia, Cáceres, 1997).

41. Santos Juliá, en su excelente Historia de las dos Españas, Madrid, Taurus, 2004, insiste en esta proclama para caracterizar el sentido de la "Cruzada" puesta en marcha el 17-18 de Julio de 1936.

42. J. Casanova, La Iglesia de Franco, Barcelona, Crítica, 2001. 
diendo algo más en una obra poética clave en la línea que apuntamos, el largo escrito de José María Pemán de 1937, titulado Poema de la Bestia y el Ángel.

Como no podía ser menos, además de las palabras y los discursos, la iconografía del bando franquista refleja esas continuas referencias religiosas que pretenden impulsarles al combate. Las consignas contienen ese inequívoco aire de pasado, de España como nación de destino metafísicamente católico, con sus gritos tradicionales: ¡Viva Cristo Rey! o ¡Santiago y cierra España! Gritos e imágenes que hacen continúa referencia a la historia española (la Reconquista, la guerra contra Napoleón, etc.) o al gran hecho histórico de las Cruzadas:

Esta tradición de Cruzada y de exaltación de la guerra como "santa violencia" se ha forjado con el correr de los siglos, en el período que empieza con la Primera Reconquista y acaba con la Nueva Reconquista, pasando por la Contrarreforma y la Guerra Santa contra la Ilustración y Napoleón, considerada como una cruzada de recristianización contra el ateísmo y el anticlericalismo ${ }^{43}$

Estos mismos autores han puesto de relieve que las referencias de este tipo no esperan a la guerra civil para expresarse, sino que se contienen ya en la propia literatura fascista española de los años treinta. ${ }^{44}$

\section{Las imágenes apocalípticas de la Iglesia de la Cruzada}

La carta colectiva de los obispos españoles -en la línea ya expresada tempranamente por Pla i Daniel- contiene algunos elementos discursivos susceptibles de ser contrapuestos a la visión "religiosa" que de la guerra de España tiene León Felipe. Así, mientras que la España republicana representaba para el poeta zamorano la España "justa", la que enlaza con la tradición auténtica del ser-español, para los obispos -cuyo documento tiene tanto de "político" como de "religioso"- el campo republicano es tildado como la "antipatria" y el sublevado como la "verdadera España"45.

También es interesante señalar que los prelados, varias veces a lo largo de la Carta, dejan claro que lo que está ocurriendo en España es una "prueba" o "castigo" divino:

Dios ha permitido que fuera nuestro país el lugar de experimentación de ideas y procedimientos que aspiran a conquistar el mundo ${ }^{46}$.

...aprendamos la lección del castigo con que Dios nos ha probado ${ }^{47}$.

43. López Campillo, op. cit., p. 138.

44. Ibídem, p. 139.

45. Carta Colectiva del episcopado español de 1 de julio de 1937 (CC), 1º Razón de este documento.

46. Ibídem.

47. Ibídem, 9. Conclusión. 
Como sabemos, también León Felipe explicaba la guerra y el sufrimiento a menudo como voluntad de "Dios" o de "estrellas dictadoras" que nos gobiernan, no tanto como pugnas ideológicas, aunque sin desconocer el papel de éstas ${ }^{48}$.

Hay una contraposición ilustrativa en la inversión de los conceptos de "justicia" y "orden" en la Carta Colectiva de los prelados y los versos de León Felipe. Como sabemos, para éste, el orden sólo podía ser -como vimos- consecuencia de la Justicia, mientras los obispos insisten radical y continuamente en la prioridad del "orden":

La paz es "la tranquilidad del orden, divino, nacional, social e individual, que asegura a cada cual su lugar y le da lo que es debido..."149

La idea de martirio -en una interpretación radicalmente contraria- está presente en ambas conciencias. Hemos insistido en la ideas de España-Cristo mártir en León Felipe, en los niños mártires inocentes que mueren bajo las bombas de la aviación franquista; mientras, para los obispos, el martirio es el que sufre la otra España:

Pero, sobre todo, la revolución fue "anticristiana". No creemos que en la historia del Cristianismo y en el espacio de unas semanas se haya dado explosión semejante, en todas las formas de pensamiento, de voluntad y de pasión, del odio contra Jesucristo y su religión sagrada ${ }^{50}$

Por último, tanto León Felipe como el episcopado español aceptan la sangre derramada por un fin superior. El poeta explicaba -en lógica cristiana- cómo la sangre del hombre es el precio para "comprar" la "luz". En un sentido más político los obispos insisten en la justificación de la guerra (acudiendo a Santo Tomás) para alcanzar la verdadera "paz"; algo que "comprende" el propio Jesús:

Siendo la guerra uno de los azotes más tremendos de la humanidad, es a veces el remedio heroico, único, para centrar las cosas en el quicio de la justicia y volverlas al reinado de la paz. Por esto la Iglesia, aun siendo hija del Príncipe de la Paz, bendice los emblemas de la guerra, ha fundado las Órdenes Militares y ha organizado Cruzadas contra los enemigos de la $\mathrm{fe}^{51}$

48. Así los obispos afirman: "La guerra de España es producto de la pugna de ideologías irreconciliables", CC, $2^{\circ}$. Naturaleza de esta carta.

49. CC. $3^{\circ}$ Nuestra posición ante la guerra.

50. Ibídem, $6^{\circ}$. Caracteres de la revolución comunista.

51. Ibídem, $3^{\circ}$. Nuestra posición ante la guerra. A ese "bendecir los emblemas de la guerra" Ilamaba León Felipe "ese arzobispo tramposo que llena de baba verde la hostia todas las mañanas y luego bendice los aviones de Franco para que asesinen a los niños indefensos de Madrid y Barcelona" (PB, "Que la justicia existe"). 
La invocación de la "Tradición" en la poética falangista de la guerra

Allí donde, precisamente, León Felipe buscaba el arsenal de imágenes y elementos con los que iluminar su combate poético-moral contra el enemigo, exactamente allí acudirán también los enemigos de la República a buscar los "temas" con los que estimular la épica del combate. Ese lugar -para la inmensa mayoría de los poetas del bando franquista- es la "tradición", la tradición religiosa, por una parte, e histórica (si es que en el caso de España caben diferencias) por la otra. Pero, ¿hablaban León Felipe y sus poetas enemigos del otro bando de la misma tradición? ¿Qué "tradición" es la continuamente invocada por los poetas del bando fascista y, en general, la tópica de todas las ideologías que lo componen? Se trata de una tradición, de una lectura de España que -como han señalado tantos autores- aborrece el siglo XVIII y el XIX, y se remonta a Isabel, Flandes, Trento o Lepanto. ${ }^{52}$ Veamos algunos ejemplos, antes de profundizar en escritores concretos, de los grandes motivos que se esgrimen en este combate.

Sin duda, del arsenal histórico-mítico de la Edad Media toma la poesía falangista innumerables motivos poéticos: la Reconquista, el Cid, la Cruzada contra el infiel... El archirrecurrente tema del Cid Campeador ("El Cid, con camisa azul, / por el cielo cabalga", Federico de Urrutia) encuentra en Don Quijote la réplica republicana de León Felipe: Don Quijote como "revolucionario" transformador de un hombre ruin y una sociedad innoble en su contrario.

El tema de la Edad media, tan reflejado en el héroe burgalés, es despreciado por León Felipe en esta significativa prosa poética:

Sólo a un fantasma que tiene el corazón y los ojos de sal cristalizada le gustaría seguir viviendo en la Edad Media.

A mí no me gustaría vivir en una edad donde los hombres luchan y caminan hacia atrás en busca del sepulcro de un dios muerto ${ }^{53}$

Para el poeta zamorano, la Edad Media válida, la que importa, es la que mira hacia delante, hacia "Compostela", hacia el Atlántico, la que está preñada de futuridad, porque va a dar a luz la Hispanidad ${ }^{54}$.

Entre los valores poderosos y auténticos de la tradición española está el "humanismo" de Velázquez (contrapuesto por León Felipe a Luis de Góngora: "Góngora era un escribano cordobés / que confundió la metáfora verbal de la cornucopia / con la intrépida metáfora demiúrgica. / ¿Por qué le haría un retrato Velázquez / a este español tramposo y retorcido / tan lejos de la luz poética verdadera / y de las nobles virtudes castellanas? / ¡Velázquez, que pintó el cuadro

52. Es interesante a este respecto acudir a la obra de Santos Juliá, Historia de las dos Españas, Madrid, Taurus, 2004. También en Rodríguez Puértolas, J., "Fascismo y poesía en España", Centro Virtual Cervantes, p. 885.

53. GL, Libro VII, "La estrella de Belén".

54. Ibídem. 
de las lanzas!")55; está el cristianismo auténtico que respira su Niño de Vallecas, donde también vuelven a aparecer los grandes héroes del poeta: Don Quijote, Sancho, Rocinante:

Y he aquí que de repente puedo decir otra vez quién soy. Este Niño de Vallecas, pintado por Velázquez, soy yo. Y tú también. Y todos los españoles del mundo ${ }^{56}$.

Castilla, su paisaje, sus valores y sus hombres, temas tópicos en la poesía "nacional", tienen correspondencia en las palabras de León Felipe:

Este es el paisaje de Santa Teresa, de San Juan, de los místicos, de la luz de Velázquez... La luz de la forja, del hierro en ignición. Bajo esta temperatura y este fulgor se ha hecho el mundo y el hombre... Y aquí ocurren los grandes milagros ${ }^{57}$.

Pero, a la vez, León Felipe ataca con ironía los tópicos "castellanos" del otro bando:

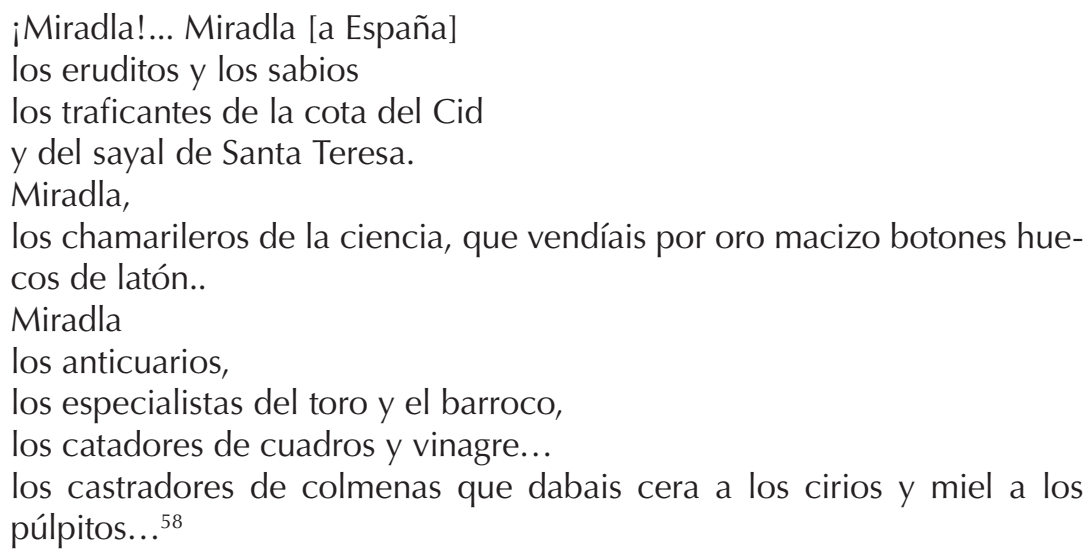

Y del sacerdote, esa figura mártir y masacrada en la retaguardia republicana, a la vez que valedor esencial también en la represión franquista y en la construcción del nuevo régimen, dice León Felipe:

...estas palabras revolucionarias, estas palabras prometeicas:

"Es más fácil que pase un camello por el ojo de una aguja que entre un rico en el reino de los cielos".

Los curas las han estado escupiendo,

55. Rocinante, "I. M. D. 1. "La intrépida metáfora demiúrgica".

56. GL., Libro VI, VII: "El Niño de Vallecas".

57. Rocinante, "IV".

58. Español del éxodo y del llanto, "¡Ya no hay feria en Medina, buhoneros!". 
vomitando desde los púlpitos, centuria tras centuria, año tras año, domingo tras domingo.

Los prelados y los obispos las han Ilevado de catedral en catedral, de iglesia en iglesia, de plática en plática y han acabado siempre por sentarse, después de los sermones, a la mesa de este rico de tan dudosa salvación, para decirle así, de una manera abierta y paladina:

El Evangelio no es más que una manera retórica de hablar ${ }^{59}$

La significación de Jesús, el Cristo, no puede ser más antitética entre nuestro poeta y los del bando franquista: España como "novia" de Cristo (Eugenio Montes). La reunión salvadora en una unidad final de reconciliación en León Felipe, bajo el concepto "Hispanidad", es -para los poetas franquistas- la negación absoluta a que Dios reconozca y acoja a los muertos de ambos bandos ("Dios sabe sus nombres / y los separa en las nubes", Pemán). Así, los poetas del fascismo tienen claro que el Altísimo no acogerá igual a quienes dieron su vida por Dios y la Patria que a aquéllos que "Nacieron sin padre /aborto del mundo son" (Ángel Gordo Moreno).

Teología y apocalipsis en la obra de José María Pemán

Imaginé inicialmente este Poema, en Noviembre de 1936, ante la fruta prohibida de Madrid, bajo los sangrientos crepúsculos de Leganés y de Getafe. Era aquella la hora austera en la que el Señor nos ordenó el desestimiento de toda idea demasiado cómoda y la aceptación rendida de la larga y grande misión histórica que quería para España.

Para terminar este breve comparación entre el cristianismo profético y moral de León Felipe y los motivos religiosos del bando franquista, nos parece revelador confrontar la poética del escritor zamorano con algunos pasajes del extenso poema épico-religioso que el joven José María Pemán publica en plena guerra civil, es decir, su Poema de la Bestia y el Ángel. Esta larga obra se inscribe en lo que nosotros consideramos un tipo de cristianismo teológicamente alimentado por las imágenes forjadas en la tradición católica española y, también evidentemente, en una interpretación alegórica del Apocalipsis de san Juan aplicado al contexto español. La vieja dualidad incompatible del siglo I entre la "puta de Babilonia" (Roma) y la Verdad revelada por Cristo, se traslada al contexto español con la misma radicalidad escatológica: el "Mal" es ahora el binomio Sión-Comunismo, mientras el bando católico franquista y su mismo Caudillo encarnan la misión redentora del "Bien". Es notable cómo mientras la poesía de León Felipe se mue-

59. GL, Libro II, "Los dos mundos". 
ve en un tipo de exigencia fundamentalmente moral, en torno al concepto de "Justicia", de un modo similar a las advertencias de los profetas del antiguo Israel, el poema de Pemán, sin referencias a los Sinópticos, se centra alambicadamente en la estructura bien-mal concebida exclusivamente en términos teológicos. Un breve repaso de algunos momentos del poema nos permitirá vislumbrar mejor al final las incompatibilidades de ambos cristianismos.

José María Pemán concibe en términos gráficamente físicos y ridiculizadores las dos caras del enemigo: así, España debe salvar a Occidente, del "peligro rojo":

soplo del Este, el maldecido

viento largo y marcero,

con un agrio quejido/

de balalaika y de desfiladero

El cual pretende ser:

...guadaña de los campanarios,

polvo del sol,

pezuña de las rosas ${ }^{60}$

La otra cara de la bestia-anticristo es el judío, sin olvidar la masonería, dibujado por Pemán con los mismos rasgos que había hecho habitual la propaganda nacionalsocialista en los años treinta: "La Logia y la Sinagoga deciden la batalla y lanzan su doble maldición" ${ }^{\prime 61}$. El judío odia la tierra, la permanencia, el suelo...: "por su amor exclusivo al oro, riqueza fluida y mobiliaria como su vida errante" ${ }^{\prime 62}$; del mismo modo que busca la destrucción de la Cruz, "odio secular de su raza". Así:

¡Campos de Extremadura!

Cortijos andaluces!

Una mano secreta desde la noche oscura

ha ordenado una siega satánica de cruces $^{63}$

La vida errante, la diáspora de este pueblo, le hace odiar la Tierra, la agricultura y la aldea, realidades de la España eterna que tienen su "canción" , lo que nos recuerda, en sentido contrario- cómo León Felipe pensaba que la derrota de la República, al significar la pérdida de la verdadera esencia del ser español, implicaba llevarse al exilio la "Canción", que es también la nana que cantan las madres y la oración, dejando "mudo" al soldado, que no es otro que el bando vencedor. ${ }^{64}$

60. J. M. Pemán, Poema de la Bestia y el Ángel, Libro I, "Visión del Octavo Candelero".

61. Ibídem., Libro III, "Las dos maldiciones".

62. Ibídem.

63. Ibídem, "La maldición de la Cruz".

64. Remitimos a la nota 41. 
Judaísmo y bolchevismo -representantes presentes del Anticristo- han tomado para Pemán la forma inocente del "cordero recental"65. España es en la tercera visión que la Bestia hace ver al cordero, la "Iglesia de Santiago, el hijo del Trueno; la Iglesia de la Esperanza". La Bestia dice al cordero que la socave lentamente, no en guerra abierta. Pemán se introduce en una interpretación de la historia de España bajo esta clave. Así, sólo la reina Isabel tuvo el valor de expulsar a los judíos. ¿Quién es el héroe español que antes de la gran contienda nos había advertido contra la presencia del Mal? Evidentemente fue José Calvo Sotelo ("protomártir de la gran Cruzada española" $)^{66}$. De allí pasará Pemán a recorrer los horrores rojos: "i iEstán crucificando un niño !!" ("En la Aldeíta de La Guardia"). ${ }^{67}$

Algunas referencias pemanianas insisten, con otra intención, en los temas de León Felipe. De esta manera, aparece una referencia a Prometeo. En el caso del poeta andaluz, Prometeo es España: "Os contaré la gran fábula prometeica de cómo España quiso robar el nuevo fuego celestial" ${ }^{168}$. León Felipe consideraba a Prometeo uno de los héroes que -como Job, Don Quijote y otros- aparecen en los momentos relevantes de la historia para, desde su sufrimiento y sacrificio personal, elevar la condición humana desde lo accidental a lo sustancial:

El genio prometeico es aquella fuerza humana y esencial que, en los momentos fervorosos de la historia, puede levantar al hombre rápidamente de lo doméstico a lo épico,

de lo contingente a lo esencial,

de lo euclidiano a lo místico,

de lo sórdido a lo limpiamente ético ${ }^{69}$

De la misma forma que León Felipe dedicaba durísimos ataques a las naciones democráticas que se lavaban las manos ante la suerte de la República española, personalizando estos ataques -como hemos visto- en Gran Bretaña (apodada frecuentemente como la "Raposa" egoísta sólo preocupada por los "negocios", como en El payaso de las bofetadas y el pescador de caña), Pemán se queja también de que el Caudillo no sea ayudado más que por Alemania e Italia ${ }^{70}$ : "Hay Pilatos melosos que se lavan las manos". Y a los EEUU llama "ipulpo grasiento de la Standard Oil!"71

65. Ibídem, Libro II, "El pacto de la Bestia y el Cordero".

66. Ibídem, Libro IV. "Visión de las tres Iglesias". Poema Protomártir.

67. Ibídem.

68. Ibídem.

69. GL, Libro III. Prometeo. 3 "El poeta prometeico".

70. Incluso para Alemania e Italia tiene León Felipe más condescendencia que para Inglaterra: “...Italia es más noble que tú / y Alemania también. / En su rapiña y en sus crímenes / hay un turbio hálito nietzscheniano de heroísmo, en el que no pueden respirar los mercaderes, / un gesto impetuoso y confuso de jugárselo todo a una carta, que no pueden comprender los hombres pragmáticos." ( $P B$, "Raposa").

71. Pemán, op. cit, "El rapto de Dios". 
El poema de Pemán avanza narrando los episodios de la guerra en tono de épica y mitificación, salpicándolos de referencias a la historia: el paso del Estrecho, la toma del Alcázar de Toledo (ciudad de Carlos $\vee$ y Recaredo, sede primada). Todo ello verdadera España, frente a la cual los denuestos a la República son atroces:

Plebeya voz de aquella mujerzuela de los pechos desnudos y del grito feroz

Como lo es la referencia a las mujeres toledanas que atacaban al clero y profanaban las cosas sagradas:

"El Cardenal del Diablo" _"El Arzobispo Rojo"

Así gritan al fondo de la calleja oscura

los bramidos de fieras

de mil hombres borrachos de locura

y mil sucias rameras

en furia de sexo hambriento y sin ternura ${ }^{72}$

El poema -para no profundizar más en él- tiene uno de sus puntos álgidos en la glorificación del héroe elegido por Dios, Francisco Franco ("Dios tiene elegido su piloto"). La exaltación del Caudillo lleva a Pemán a equiparar su nacimiento con el del propio Jesús:

Y allí [en El Ferrol, en Galicia] ha sido la dádiva suprema, del Señor.

Allí por la maroma de plata centelleante de una luna indecisa de diciembre, con son navideño, bajaban de la mano tres hadas como la aurora, blancas y rubias como el sol.

Hay una cuna blanca que espera la visita y en la cuna una vida frágil como una flor.

Las hadas disputaban sobre cuál le traía un presente mejor $^{73}$

Nada puede situarse más en las antípodas de la caracterización de Franco por León Felipe, para el que era, simplemente, quien -bajo la bendición eclesiásticaasesinaba "a los niños indefensos de Madrid y Barcelona". ${ }^{74}$

72. Ibídem, "El Alcázar".

73. Ibídem, Canto II, "Los dones de las tres hadas".

74. $P B$, "Que la justicia existe". 


\section{Final}

León Felipe siempre ha ocupado un lugar extraño entre los poetas del bando republicano que se batieron en la Guerra Civil y, o murieron, o conocieron el exilio. Tampoco sería justo hablar desde luego, de un lugar "marginal". Si, por ejemplo, recordamos cómo los llamados cantautores españoles, sobre todo en la década de los años setenta, fueron los grandes divulgadores de los poetas "republicanos" (nos referimos a los J. M. Serrat, Luis Pastor, Paco Ibáñez, Pablo Guerrero, Adolfo Celdrán, y tantos otros), no podemos decir que ignoraran la obra poética de León Felipe. Casi todos ellos musicaron una o varias de sus letras, como la conocida "Vencidos" de J. M. Serrat, "Canción Marinera" de Luis Pastor o "¡Qué pena!" de Adolfo Celdrán. ${ }^{75}$

Sin embargo, León Felipe no es, ni de lejos, un poeta típico del repertorio de aquel movimiento, ni ha sido apenas estudiado por los estudiantes de literatura en nuestro Bachillerato. No, desde luego, al nivel de los Machado, Alberti, Lorca o Miguel Hernández, por ejemplo. ¿Se trata solo de una hipotética menor calidad poética, o existe alguna especial extemporaneidad en su poesía, en su métrica, en sus temas?

Hemos visto a lo largo de este artículo la situación siempre intempestiva de León Felipe, como poeta demasiado religioso en el bando de los irreligiosos, demasiado "no partidista", áspero y poco generador de eslóganes políticos. Un temperamento más bien "ácrata", ridiculizador feroz de las menudencias ideológicas y programáticas que hicieron estragos en el bando leal a la República. Hay sin duda en él una especial adicción a lo violentamente individual que no soporta otro horizonte que la libertad, por lo que lo nos hemos atrevido a adjetivar como ácrata a un hombre sin carnet de partido o sindicato. Pasión por la individualidad y la libertad radical que nos recuerda al viejo Bakunin, por ejemplo, claro que sin el radical ateísmo de aquel orgulloso librepensador del siglo XIX. León Felipe hubiera sin duda firmado estas famosas palabras del aristócrata ruso:

Sólo soy verdaderamente libre cuando todos los seres humanos que me rodean, hombres y mujeres, son igualmente libres [...] de modo, pues, que cuantos más sean los hombres libres que me rodean y más profunda y amplia sea su libertad, más extensa profunda y amplia lo será la mía... sólo puedo decirme verdaderamente libre cuando mi libertad, o, lo que es lo mismo, cuando mi dignidad de hombre, mi derecho humano, reflexionados por la conciencia igualmente libre de todos, vuelven a mí confirmados por el asentimiento de todo el mundo ${ }^{76}$

75. "Vencidos" apareció en el LP de Joan M. Serrat, Mediterráneo (1971); "Canción Marinera" en el disco Fidelidad (1975), de Luis Pastor y “Qué Pena!” en Silencio (1970) de Adolfo Celdrán.

76. Cita de M. Bakunin, extraída de www.mundolibertario.org. 
Ese "anarquismo" del poeta -si se nos permite la expresión- se materializa también en el terreno religioso ${ }^{77}$. Un aliento religioso que en León Felipe -como hemos pretendido demostrar-, y sin renunciar a otras importantes influencias, constituye el núcleo central generador de su pensamiento y de su visión del hombre, de la sociedad y de la vida. El hombre como "exiliado" de la existencia no es en absoluto una imagen ajena a la tradición occidental; por no ir más atrás, está presente en Platón, en Pablo, en los -indudablemente influidos por lo platónico- primeros Padres cristianos. El hombre, asimismo, como "debilidad" es tema recurrente en la concepción paulina, tal como podemos rastrearla a lo largo de toda la Epístola a los Romanos; imagen que indudablemente tiene su continuidad en Lutero y en tantos otros reformadores. La paradoja de León Felipe consiste, tal vez, en que de una antropología sin duda tan pesimista ("La manzana roja que me dieron a comer ayer tenía un gusano: / La manzana blanca que se comieron mis padres tenía dos gusanos; / y la manzana verde que se comió la pareja original, ya en la puerta falsa del Paraíso, tenía ya tantos gusanos que todos pudimos heredar nuestra parte" ${ }^{\prime 8}$ ) derive una concepción político-social de características progresistas y aún revolucionarias, que encontraron su lugar de expresión en el compromiso completo del poeta con la causa de la II República española; causa que continuó intensamente viva en el poeta en su exilio mejicano hasta su muerte, treinta años más tarde.

El otro aspecto que hemos querido resaltar en este artículo es la naturaleza radicalmente antitética entre el cristianismo de León Felipe y el nacionalcatolicismo de los escritores del bando franquista, por decirlo en términos simples. Esperemos que haya quedado patente a lo largo de las citas expuestas. Un cristianismo que -a pesar de esa antropología pesimista que señalábamos- tomaba una expresión voluntarista y activa en la esfera de la actividad del hombre, conducente a saber quién es y qué espera Dios de él. Una voluntad que entiende -como Don Quijote a la vista de venteros y prostitutas- que la realidad no puede ser tan sórdida y, en consecuencia, debe esperar al hombre -después, eso sí, de un purgatorio vital (lágrimas) - una salida escatológica a la luz, a la Justicia...; es decir, una suerte laicizada de consumación de los tiempos cristiana ("Toda la luz del mundo la verá un día el hombre / por la ventana de una lágrima") Esa dual naturaleza pesimista pero esperanzada de redención en León Felipe sólo se resuelve, pues, en actitudes ético-morales que se traducen en el compromiso absoluto con republicanos perdedores y niños desvalidos e inocentes bajo las bombas franquistas, haciendo buenas las palabras de Mateo 25, 4079. Ese "apostolado"

77. "Anarquista santo" era la definición que de Jesús daba Nietzsche en El Anticristo (Introducción, traducción y notas de Andrés Sánchez Pascual, Madrid, Alianza, 1972).

78. Ver nota 18.

79. "Y respondiendo el Rey, les dirá: De cierto os digo que en cuanto lo hicisteis a uno de estos mis hermanos más pequeños, a mí lo hicisteis". 
toma poéticamente en León Felipe la forma pasiva, paciente, del Cristo-Mártir y la activa de Don quijote liberador de galeotes ${ }^{80}$.

En este sentido, hemos querido resaltar, plásticamente, cómo las mismas imágenes y categorías religiosas pueden servir para propósitos y concepciones vitales y morales tan diametralmente opuestos. Lo que en León Felipe tomaba los derroteros de una religión entendida como vínculo ético de acción, se tornaba en los escritores del otro bando en una lectura histórico-teológica del mundo y de España. Como lectura escatológica, ellos dibujaban un panorama tan dualista como el de León Felipe -bando de la luz y de las tinieblas- pero, claro está, invirtiendo los términos. A nosotros nos parece oír la autenticidad del grito del hombre en la poesía de León Felipe, y la vacuidad retórica y la pomposidad estilística en los versos de Pemán, sin que pretendamos con ello negar la sinceridad en la emoción y la pasión en el compromiso con su bando del joven poeta gaditano.

La voz de León Felipe confrontada con la de obispos y poetas falangistas católicos, a pesar de la elevación de su tono por el momento concreto y dramático de la España de los años treinta, constituyen casi una repetición, o más bien un anticipo, de las constantes tensiones ideológicas en el seno del cristianismo-catolicismo; tensiones propias de las últimas décadas entre un cristianismo profético de denuncia social y un catolicismo tibio, acomodado a la molicie de la confortable Europa del Bienestar. Modorra de la que Francisco parece quererlo despertar. León Felipe ha preludiado -a nuestro juicio- a aquellas voces religiosas que, pegadas al sufrimiento concreto del ser, arrancan la acción transformadora desde la realidad de los pobres y oprimidos, desde el grito del Hijo: "Padre, ¿por qué me has abandonado?"81. Cristianismo de la rebelión que no se podía conformar con la salvación como asunto individual; cristianismo de la rebelión que solo podría descansar cuando -como Don Quijote en la imagen unamuniana- dejara los infiernos vacíos. León Felipe encarnó esa religión que es soplo del espíritu:

Volveré mañana en el corcel del viento.

Volveré. Y cuando vuelva, vosotros os estaréis yendo:

vosotros los alcabaleros de la muerte, los centuriones en acecho

bajo la gran ojiva de la puerta, los constructores de ataúdes que, al medir el cuerpo amarillo de los que se van, con la cinta de metro y medio de los alfayates, decís siempre; ¡cómo crecen los muertos!

¡Oh, sí! Los muertos crecen. El último traje que se hicieron, al amortajarlos ya les viene pequeño.

80. El Quijote I, cap. XXII.

81. Marcos 15, 34. En palabras de Jürgen Moltmann: "Toda teología y toda existencia cristianas responden, en realidad, a esta pregunta de Jesús. También el ateísmo de las protestas y las rebeliones metafísicas contra Dios responde a esta pregunta" (El Dios crucificado, Salamanca, Sígueme, 2010, p. 13). 
Crecen. Y apenas los entierran, rompen los tablones de pino y los catafalcos de acero;

Crecen después en la tumba, fuera de la caja, abren la tierra como las semillas del centeno

y ya, bajo el sol y la lluvia, en el aire, sueltos, y sin raíces, siguen y siguen creciendo.

Yo me voy a crecer con los muertos.

Volveré mañana en el corcel del Viento.

Volveré, iy volveré crecido! Entonces vosotros que os estaréis yendo no me conoceréis. Mas cuando nos crucemos

en el puente, yo os diré con la mano:

¡Adiós, alcabaleros,

centuriones,

sepultureros!...

A crecer, a crecer,

a la tierra otra vez...

al agua,

al sol,

al Viento... al Viento...

¡Otra vez al Viento! ${ }^{82}$

\section{Bibliografía}

ALFONSO SÁNCHEZ, J. M., "La carta colectiva del episcopado español (1 de julio de 1937)", Papeles Salmantinos de Educación, 0, 2001.

CASANOVA, J., La Iglesia de Franco, Barcelona, Cátedra, 2001.

JULIÁ, S., Historia de las dos Españas, Madrid, Taurus, 2004.

LEÓN FELIPE, Poesías Completas; edición de José Paulino, Madrid, Visor, 2004.

LEÓN FELIPE, Ganarás la luz, edición, introducción y notas de José Paulino, Madrid, Cátedra, 1982.

LÓPEZ CAMPILLO, E. y otros, "Una cruzada para una nueva Tierra Santa ¡Fraternidad, Libertad, Igualdad!", Norba, 14, 1997, pp. 137-146.

PEMÁN, J. M., Poema de la Bestia y el Ángel, Pamplona, Ediciones Jerarquía, 1938.

PEÑAlVA, J. J., “Poema de la Bestia y el Ángel, de Pemán: Configuración literaria de un estética de Guerra", Hesperia, VI, 2003.

PUCHE GUTIÉRREZ, M. T., "León Felipe sincrónico y anacrónico. Un estudio de literatura comparada". Tesis doctoral dirigida por Antonio Chicharro Chamoro, Universidad de Granada, 2009. http://hera.ugr.es/tesisugr/18157968.pdf.

82. GL, Epílogo, XI: "Me voy porque la tierra y el pan y la luz ya no son míos". 
RODRÍGUEZ PUÉRTOLAS, J., "Fascismo y poesía en España", Centro Virtual Cervantes. http://cvc.cervantes.es/literatura/aih/pdf/07/aih_07_2_038.pdf.

TRECCA, S., "La poética del éxodo de León Felipe: Una lectura intertextual de Español del éxodo y el llanto y Ganarás la luz", Castilla. Estudios de Literatura, 1, 2010, pp. 275-309. 